\title{
Seismic hazard microzonation of Bengkulu City, Indonesia
}

\author{
Lindung Zalbuin Mase ${ }^{1^{*}}$, Nanang Sugianto ${ }^{2}$ and Refrizon ${ }^{2}$
}

\begin{abstract}
It has been known that Bengkulu City (Indonesia) is vulnerable to undergo seismic damage. This study is initiated by measuring horizontal to vertical spectral ratio (HM) to sites in Bengkulu City using microtremor. The inversion analysis is performed to generate shear wave velocity profile. Hundreds of sites are investigated in this study. The results show that observed HN is consistent with the theoretical HN. National Earthquake Hazard Reduction Program code is adopted to classify the site class. The results also exhibit that Bengkulu City is dominated by Site Classes C and D. In general, this study could lead local government to consider seismic hazard mitigation for spatial plan.
\end{abstract}

Keywords: Earthquakes, Shear wave velocity, Microtremor, Site class, Bengkulu

\section{Introduction}

Bengkulu City is a capital city of Bengkulu Province, Indonesia. The city is located at the western part of Sumatera Island, which is bordered with Indian Ocean. Recently, the city has been promoted as one of tourist destinations in Indonesia. However, earthquakes have been identified as the main issue in Bengkulu City since last two decades. Mase (2017) reported that at least two major earthquakes had occurred within last two decades. The first strong earthquake happened on June 4, 2000, with magnitude of $\mathrm{M}_{\mathrm{w}} 7.9$ (the Bengkulu-Enggano Earthquake) and the second strong earthquake happened on September 12, 2007 with magnitude of $M_{w} 8.6$ (the Bengkulu-Mentawai Earthquake) (Fig. 1). Misliniyati et al. (2018) noted that those devastating earthquakes had triggered huge damage to structural buildings and lifelines facilities. Those earthquakes also triggered liquefactions along coastal area of Bengkulu City (Mase, 2017). Learning from those events, the effort to escalate seismic hazard mitigation in Bengkulu City should be prioritised (Mase, 2020).

\footnotetext{
* Correspondence: Imase@unib.ac.id

'Department of Civil Engineering, Faculty of Engineering, University of Bengkulu, WR Supratman Road, Kandang Limun, Muara Bangkahulu, Bengkulu 38371, Indonesia

Full list of author information is available at the end of the article
}

Studies of earthquake hazard in Bengkulu City had been performed by several local researchers. Mase (2017) performed analysis of liquefaction potential along coastal area of Bengkulu Province. Mase (2017) highlighted that liquefaction could happen along coastal area of Bengkulu City, especially during the BengkuluMentawai Earthquake. Mase (2018) performed a reliability study of designed spectral acceleration for structural buildings in Bengkulu city and found that spectral acceleration resulted during seismic wave propagation had exceeded the designed spectral acceleration. Mase (2018) suggested that it is important to propose the updated design. Mase (2018) also recommended that seismic amplification effect should be considered in composing the updated designed spectral acceleration. Farid and Hadi (2018) investigated ground shear strain $(\gamma)$ in Bengkulu City based on microtremor measurements. Farid and Hadi (2018) found that Bengkulu City is dominated by alluvium materials. Those materials are composed of sandy soils, which are very sensitive to undergo liquefaction during earthquakes. Mase et al. (2020a) and Mase (2020) conducted a seismic hazard microzonation of ground response parameters in Bengkulu City and proposed the local seismic design that could be used in Bengkulu City. Mase et al. (2021) performed the study of local site investigation and ground response analysis on 


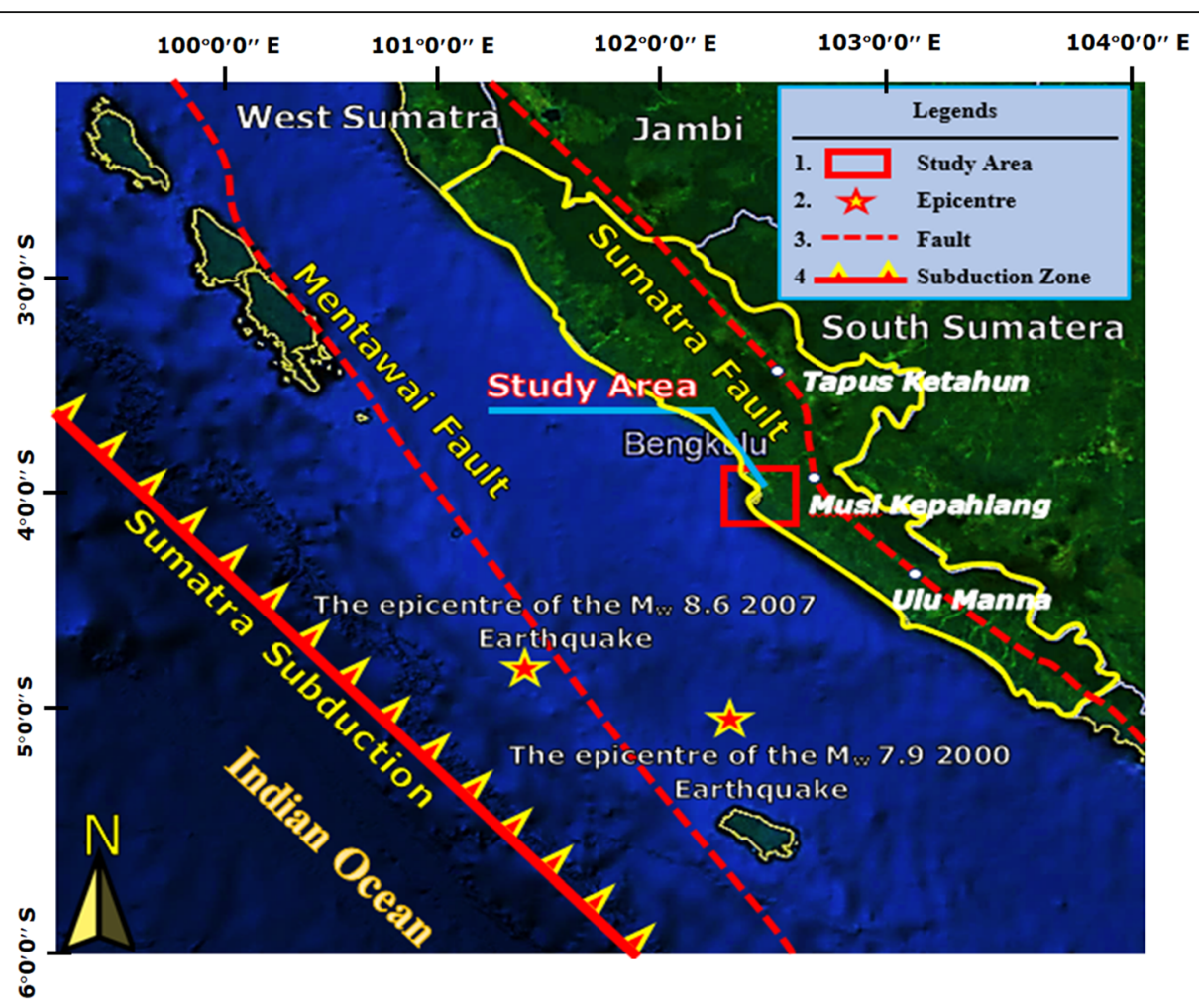

Fig. 1 Seismotectonic settings of Bengkulu Province, Indonesia and the epicentres of major earthquake on Bengkulu Province

downstream area of Bengkulu City and found that liquefaction and seismic amplification could happen. Mase (2021) presented a study of ground motion characteristic of the Bengkulu-Mentawai Earthquake and the earthquake impacts to the northern part of Bengkulu Province and suggested that the lesson learned from the earthquake is important to develop Bengkulu Province. Generally, those previous studies had presented preliminary investigation on soil damage during earthquakes in Bengkulu City. However, seismic microzonation study related to local site condition has not performed yet.

Subsurface geophysical measurements included two major methods, which are widely known as passive and active methods. The implementation of passive method using microtremor is more preferable. Workability, low cost, and accuracy are some reasons why this method is more chosen. Several researchers, such as Gosar (2010), El-Hady et al. (2012), and Mase et al. (2020b, 2020c) had performed microtremor measurements for site investigation. Generally, those previous studies emphasised on depicting site characteristic based on time-averaged shear wave velocity for first $30 \mathrm{~m}$ depth $\left(V_{s 30}\right)$. Mase et al. (2020b) suggested that $V_{s 30}$ is the important parameter to describe seismic vulnerability in an area. It is therefore very useful to be implemented in the area with high seismic intensity, such as Bengkulu City, Indonesia (Mase, 2019).
In line with the previous studies, the local site investigation and seismic hazard mitigation in Bengkulu City is still rarely presented. This paper presents a seismic microzonation study. The microtremor measurement and site investigation were performed at hundreds of sites in Bengkulu City. The horizontal to vertical spectral ratio $(H / V)$ is obtained from measurement. Furthermore, the inversion analysis is performed to generate shear wave velocity $\left(\mathrm{V}_{\mathrm{s}}\right)$ profile. $\mathrm{V}_{\mathrm{s}}$ profile is then analysed to determine $V_{s 30}$, which is used to classify site condition. This study also presents seismic hazard map and $V_{s 30}$ map. In general, the results could provide information about seismic vulnerability in Bengkulu City, which can be used as a reference in developing the city on the basis of seismic hazard mitigation.

\section{Seismotectonic setting}

Bengkulu Province has been known as an area, which has a high seismic intensity (Mase, 2017). In Fig. 1, seismotectonic setting of Bengkulu Province is presented. There are three active tectonic settings which frequently triggered earthquakes in Bengkulu Province and its surrounding areas. The first earthquake source is Sumatra Subduction. This zone is the plate boundary between the Eurasian Plate and the Indo-Australia Plate. This subduction zone had triggered the Bengkulu-Enggano Earthquake and the Bengkulu-Mentawai Earthquake). 
In Sumatra plain, a large fault system crossing Sumatra Island exists. This zone is known as Sumatra Fault System (Rusydy et al., 2020). This fault system is categorised as slip strike fault. Sieh and Natawidjaja (2000) mentioned that Sumatra Fault is situated between subduction zone in Southern Java and oblique subduction system in Sumatra. McCaffrey (2009) mentioned that this fault is associated with the oblique convergence between Indo-Australian Plate and Eurasian Plate. The earthquake history recorded that this fault had triggered both the $\mathrm{M}_{\mathrm{w}} 6.8$ Liwa Earthquake and the $\mathrm{M}_{\mathrm{w}}$ 7.9 Alahan Panjang Earthquake in 1994 (Widiwijayanti et al., 1996 and Natawidjaja and Triyoso, 2007). Another active fault, which is known as Mentawai Fault System is located between Sumatra Subduction and western coast of Sumatra (Sieh and Natawidjaja, 2000). The Mentawai Fault system is also categorised as strikeslip fault zone. This fault had triggered a major earthquake, which was known as the $M_{w} 7.6$ Padang Earthquake in 2009 (McCloskey et al. 2010).

\section{Geological condition}

Figure 2 presents the geologic map of Bengkulu City. Generally, alluvium terrace (Qat) sediment is dominant, especially along coastal area up to middle part of Bengkulu City. Qat is composed of sediment materials, such as sand, silt, clay, and gravel. Mase (2017) mentioned that during the $M_{w} 8.6$ Bengkulu-Mentawai Earthquake, liquefaction evidence had been found on sites dominated by Qat. The reef limestone $(\mathrm{Ql})$ is also found on coastline parts. Shallow soil deposits composed of sandy soils were underlain by reef limestone. At the borders between Central Bengkulu Regency and Seluma Regency and at several northern parts of Bengkulu City, Bintunan formation $(\mathrm{QTb})$ is found. This formation is composed of rocks, such as polymictic conglomerate, breccia, reef limestone, tuffaceous claystone, and wood fossil. In the eastern part of Bengkulu City, which is bordered with Central Bengkulu Regency and Seluma Regency, Andesite (Tpan) formation is found. This area is known as high terrain area in Bengkulu City. Swamp deposit (Qs) is found in northern and western parts. This deposit consisted of sand, silt mud, clay and plant fossil. Alluvium $(\mathrm{Qa})$ deposit is dominant in the middle part of Bengkulu City. Several materials, such as boulder, gravel, sand, silt, mud, and clay, are identified as the composing materials (Natural Disaster Agency of Bengkulu Province, 2018).

Mase et al. (2018b) had presented typical geological condition of Bengkulu City (Fig. 3). Generally, typical subsoils in Bengkulu City are composed of three main materials, i.e. clayey soil, sandy soil, and rock. Clayey soils, such as organic clay $(\mathrm{OH})$, high plasticity clay $(\mathrm{CH})$, and silty clay $(\mathrm{CM})$ are found at first two layers. These layers have cone resistance $\left(q_{c}\right)$ of 2 to $30 \mathrm{~kg} / \mathrm{cm}^{2}$ and $V_{s}$ of 94 to $353 \mathrm{~m} / \mathrm{s}$. Furthermore, granular soils composed of silty sand (SM), poor-graded sand (SP), clayey sand (SC), and clayey gravel (GC) are found at third and fourth layers, with $q_{c}$ of 30 to $250 \mathrm{~kg} / \mathrm{cm}^{2}$ and $\mathrm{V}_{\mathrm{s}}$ of 200 to $614 \mathrm{~m} / \mathrm{s}$. The soft-rock composed of sandstones is generally found below those sand layers. This rock layer has $q_{c}$ more than $250 \mathrm{~kg} / \mathrm{cm}^{2}$ and $\mathrm{V}_{\mathrm{s}}$ of 476 to $760 \mathrm{~m} / \mathrm{s}$.

\section{Theory and methodology} $\mathrm{H} / \mathrm{V}$ method

Several researchers, such as Lachet et al. (1996), Bard (2004), El-Hady et al. (2012), and Mase et al. (2020b) had implemented microtremor measurement to observe local site condition. In its applicability, horizontal motion of microtremor, which is composed of shear waves, is used as measurement assumption. Predominant period $\left(T_{0}\right)$ and Horizontal to Vertical Spectral Ratio $(H /$ $V)$ are estimated based on horizontal motions spectra which reflect the transfer function at investigated site.

The use of $H / V$ method was firstly introduced by Kanai and Tanaka (1954) (popularised by Nakamura (1989)). This method is derived from spectral ratio of horizontal motion, which is transferred from microtremor measurement. Mase et al. (2020b) mentioned that $H / V$ method is reliable to expect $\mathrm{V}_{\mathrm{s}}$ profile. Atakan (2009) explained that $H / V$ from earthquake shaking recorded on sediment surface to bedrock surface is generally consistent with $H / V$ from microtremor measurement. Lachet and Bard (1994) suggested that $H /$ $V$ method can be used to estimate predominant frequency. Lachet and Bard (1994) also mentioned that $H /$ $V$ method can result in the expected estimation of site response of sediment soil deposits. $H / V$ is calculated by comparing Fourier Spectra between horizontal components and vertical component, as expressed in the following equation,

$$
H / V=\sqrt{\frac{H_{(E W)}^{2}+H^{2}{ }_{(N S)}}{2 V^{2}}}
$$

where, $H_{(E W)}$ and $H_{(N S)}$ are the Fourier amplitude spectra of horizontal in east-west and north-south directions, respectively, and $V$ is vertical spectra value.

Lachet et al. (1996), Koçkar and Akgün (2012), Mase (2019), and Mase et al. (2020c) highlighted that $H / V$ Method is very useful in predicting local site condition. Spectral ratios obtained from $H / V$ method is relatively more stable than other raw noise spectra. Koçkar and Akgün (2012) mentioned that $f_{O}$ is well correlated to peak of $H / V$ amplitude $\left(A_{0}\right)$. However, noises caused by human activities, environmental settings, and other active vibration sources at surface could affect measurement quality. Therefore, measurement should be 


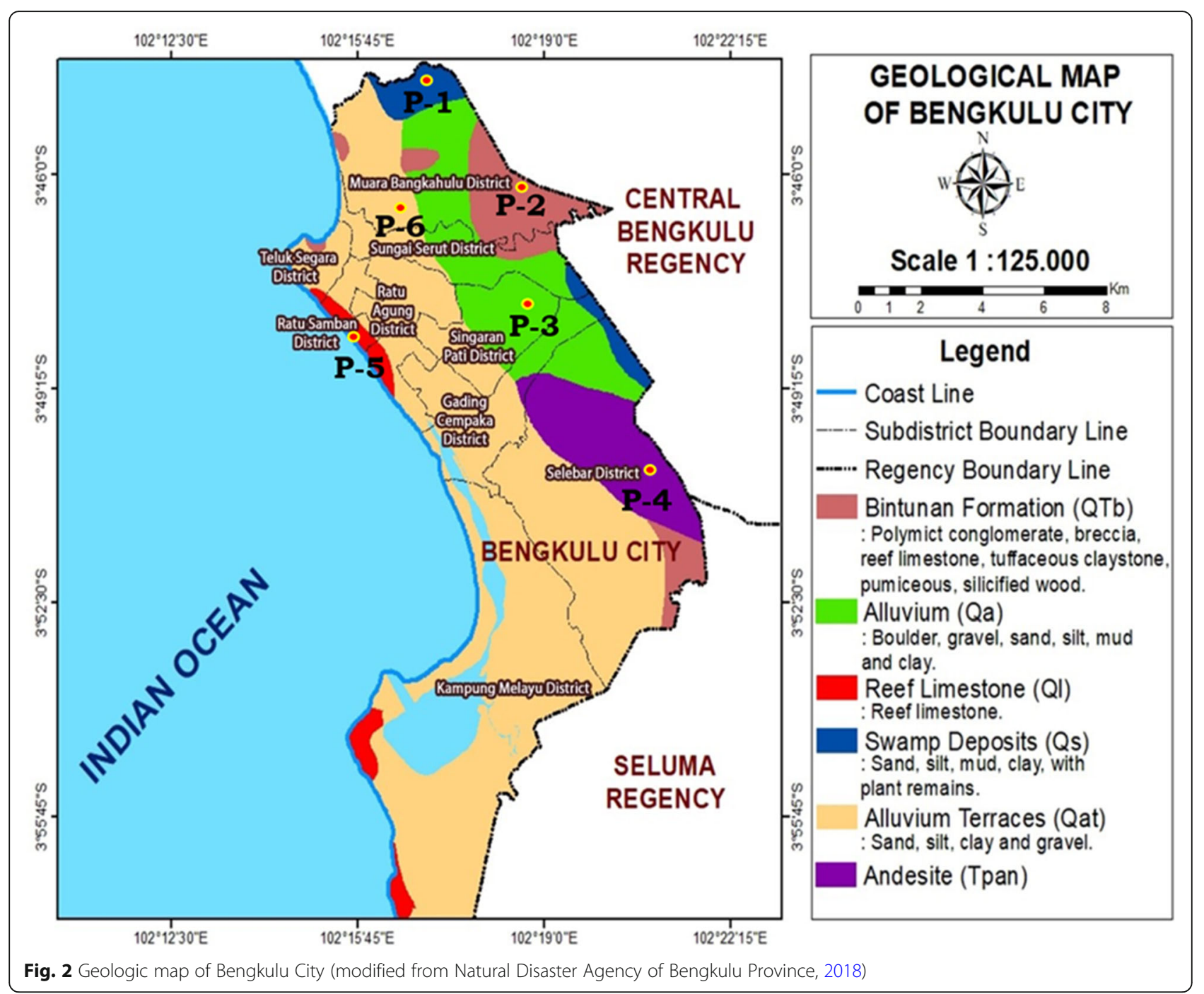

carefully performed to ensure the appropriate result. Bonnefoy-Claudet et al. (2006) stated that $H / V$ method is effective to predict predominant frequency $\left(f_{o}\right)$ (simply predicted by $1 / T_{0}$ ). Raptakis et al. (2005) explained that even though the limitation of $H / V$ has been recognised, the method is still widely used. SESAME (2004) compiled the criteria to determine the clear peak of $H / V$ amplitude, which could help engineers to determine site condition for engineering practice (the detail can be found in SESAME (2004)).

In this study, a triaxial geophone-broad band seismometer called PASI Gemini is used to measure microtremor on each site. The seismometer consisted of three components, i.e. east-west $(E W)$, north-south $(N S)$, and up-down $(U D)$. The equipment is also applicable to measure strong and weak motions. The digitisers are let to warm up for $5 \mathrm{~min}$ before measurement. This treatment is expected to avoid problem of low frequency range and to obtain reliable data. Each measurement is performed with the duration of $30 \mathrm{~min}$. Once the measurement is completed, noises from recorded data are removed and processed based on SESAME (2004) criteria. Results are then analysed to generate $H / V$ curve. Next, $H / V$ curve is analysed to generate $\mathrm{V}_{\mathrm{s}}$ profile. In this study, the inversion technique introduced by García-Jerez et al. (2016) is used. The inversion of $H / V$ is computed based on Monte Carlo sampling simulated annealing (García-Jerez et al., 2016).

The adopted model from García-Jerez et al. (2016) required several parameters for each layer. Those parameters are soil thickness, pressure wave velocity $\left(V_{p}\right)$, shear wave velocity $\left(\mathrm{V}_{\mathrm{s}}\right)$, soil density $(\rho)$, and Poisson's ratio $(v)$. The assumption of elastic half-space is adopted for the bottom layer. In Monte Carlo Simulation, each parameter is ranged from minimum to maximum value, which is defined from a-priori knowledge of soil properties (Wathelet, 2008). In this study, values of required parameters are taken from the information of typical soil 


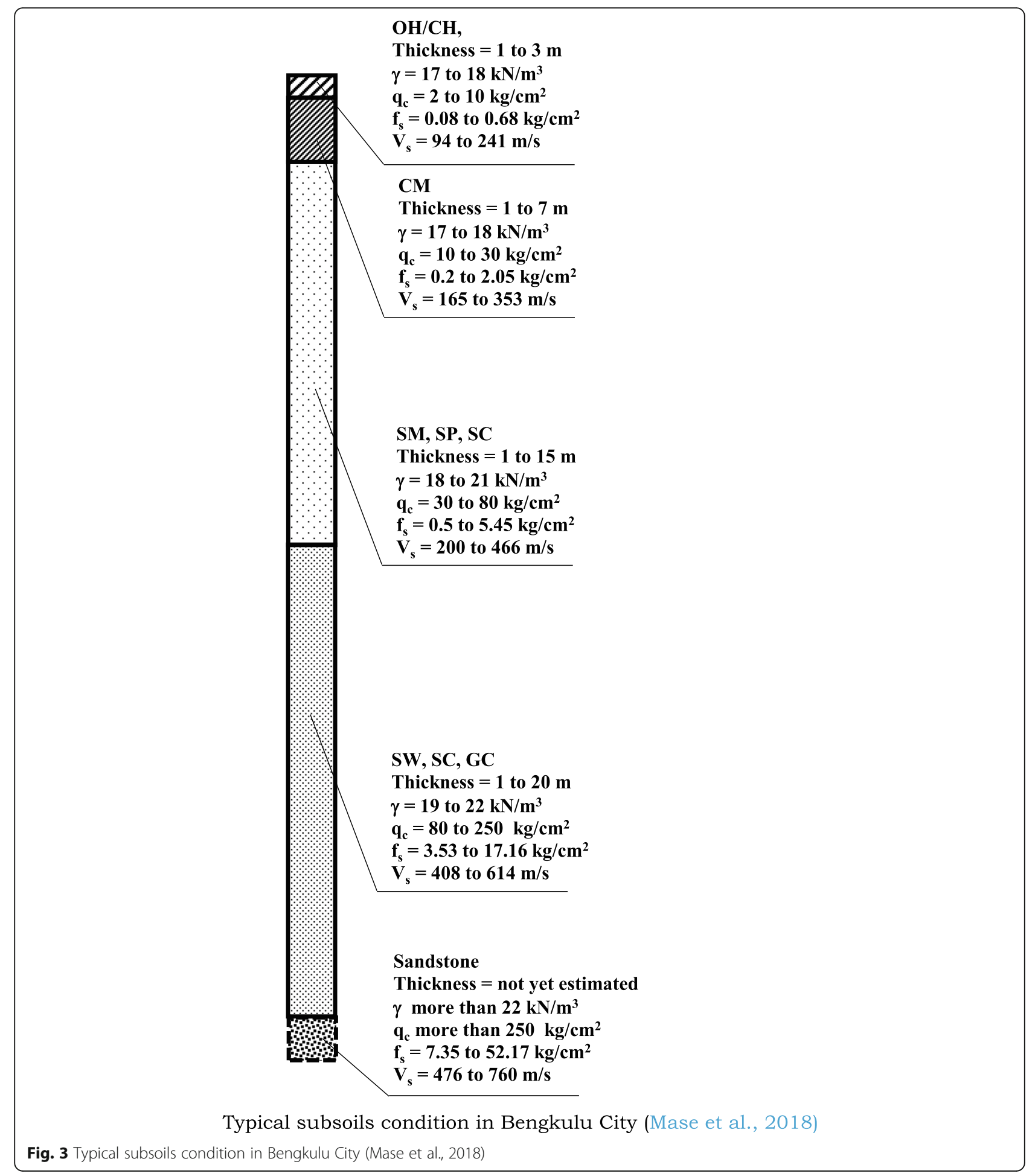

layer in Bengkulu City. $\mathrm{V}_{\mathrm{s}}$ is derived from the correlation provided by Imai and Tonouchi (1982). $\mathrm{V}_{\mathrm{s}}$ may be also predicted from the elastic theory, which is related to Poisson's ratio and elastic modulus (Salencon, 2001). To predict $V_{p}$, ratios of $V_{p} / \mathrm{N}_{\mathrm{s}}$ are also firstly assumed in the model (Tatham, 1982). Several researchers, such as
Wathelet (2008), García-Jerez et al. (2016), Mase et al. (2020b), and Mase (2019) stated that several parameters including $V_{p}, \mathrm{~V}_{\mathrm{s}}$, and Poisson's ratio could be categorised as the interdependent parameters. The Monte Carlo simulation is initiated with the starting guess model whose parameters are randomly selected within 
the ranges listed in Table 1 . The velocity profiles and other parameters are calculated repeatedly until both measured $H / V$ curve and calculated $H / V$ curve are consistent each other.

\section{Site classification}

National Earthquake Hazard Reduction Provision (1998) introduced the criteria to classify local site condition. The criteria were derived based on $V_{s 30}$ as expressed in this following equation,

$$
V_{s 30}=\frac{30(\mathrm{~m})}{\sum_{i=1}^{n} \frac{d_{i}}{V_{s i}}}
$$

In Eq. $2, d_{i}$ is the thickness of each layer, $V_{s i}$ is $\mathrm{V}_{\mathrm{s}}$ on each layer, and $n$ is the number of layers for first $30 \mathrm{~m}$ depth. The criteria to determine site classification based on $V_{s 30}$ are summarised in Table 2. Generally, the identification of site classification is very important in earthquake engineering practice. Zhao and $\mathrm{Xu}$ (2013), Adampira et al. (2015), Dev and Nagarajan (2017), Mase et al. (2018a, 2018c), Misliniyati et al. (2019), Likitlersuang et al. (2020), Tao and Rathje (2020) mentioned that the information of $\mathrm{V}_{\mathrm{s}}$ for first $30 \mathrm{~m}$ depth is necessary to observe soil response during seismic wave propagation. In this study, the interpretations of site classification and shear wave velocity are elaborated.

\section{Methodology}

This study is systematically performed based on flow chart presented in Fig. 4. This study is initiated by capturing geo-hazard issue in Bengkulu City. Several studies related to earthquake aspect and geological condition of Bengkulu City were reviewed. Furthermore, data collection (cone penetration test or CPT and microtremor measurement) was performed. CPT was addressed to obtain geological condition. CPT was also used as a consideration in determining starting guess model. Microtremor measurement on each site was recorded by using PASI seismometer. Secondary data used in this study were geologic map of Bengkulu City, typical geological condition, and topography map. Geologic map and typical geological condition would help to understand characteristic of subsoils in Bengkulu City. For accessibility information to the sites, topography map was useful in this study. There were 183 microtremor points and 32 CPT points measured in this study. In addition, standard penetration tests (SPT) were performed at representative sites (P-1 to P-6 points in Fig. 2).

After the data collection, the data analysis was conducted. At this stage, microtremor record on each site is processed to generate $H / V$ curve. To obtain the reliable $H / V$ curve, the results were examined by SESAME (2004) criteria. If $H / V$ curve was not fulfilled the criteria, measurement would be repeated. In this study, several $H / V$ curves representing each geological condition in Bengkulu City (Fig. 2) were also elaborated.

Afterwards, inversion analysis was performed. In this study, the model adopted from García-Jerez et al. (2016) was used. The initial model was considered based on geological condition of Bengkulu City (Fig. 3 and Table 1). The model would randomly seek the best model based on the ranges. From inversion analysis and measurement, several issues, such as $H / V$ curve, $A_{0}, f_{0}$ and the comparison of $\mathrm{V}_{\mathrm{s}}$ profil, and seismic microzonation map based on $V_{s 30}$ were elaborated in this study. In general, this study could describe seismic hazard vulnerability in Bengkulu City.

\section{Results and discussion Measurement results}

To obtain the description of geophysical characteristic in Bengkulu City, several $H / V$ curves (P-1 to P-6) which represent each geological formation in Bengkulu City (Fig. 2), are presented in Fig. 5. All $H / V$ curves have been also fulfilled the criteria of SESAME (2004).

In Fig. 5, several $H / V$ curves with sharp clear peak have been demonstrated by Fig. 5b, c, and e that represent P-2, P-3, and P-5, respectively. Those sites are located at QTb, Qa, and QI, respectively. For P-2, $A_{0}$ is 6.81 and $f_{O}$ is $6.02 \mathrm{~Hz}$. $A_{O}$ values for P-3 and P-5 are 4.58 and 2.30, respectively, whereas $f_{0}$ values for P-3 and P-5 are 7.52 and $6.59 \mathrm{~Hz}$, respectively. A large $A_{O}$ indicates that there is a large impedance contrast between sediment and bedrock in a site. Meanwhile, a large $f_{O}$ means

Table 1 Range values of initial parameters for H/N inversion

\begin{tabular}{|c|c|c|c|c|c|c|}
\hline Layer & $\begin{array}{l}\text { Soil Type } \\
\text { USCS }\end{array}$ & $\begin{array}{l}\text { Thickness } \\
\text { [m] }\end{array}$ & $\begin{array}{l}V_{s} \\
{[\mathrm{~m} / \mathrm{s}]}\end{array}$ & $\begin{array}{l}V_{p} \\
{[\mathrm{~m} / \mathrm{s}]}\end{array}$ & $\begin{array}{l}\text { Density } \\
{[\rho]\left[\mathrm{kg} / \mathrm{cm}^{3}\right]}\end{array}$ & $\begin{array}{l}\text { Poisson Ratio } \\
\text { [v] }\end{array}$ \\
\hline 1 & $\mathrm{OH} / \mathrm{CH}$ & $1-20$ & $90-270$ & $125-375$ & $1800-2000$ & $0.400-0.495$ \\
\hline 2 & $C M$ & $1-20$ & $160-350$ & $240-525$ & $1800-2000$ & $0.400-0.495$ \\
\hline 3 & SM, SP, SC & $1-20$ & $200-500$ & $300-750$ & $1800-2000$ & $0.200-0.400$ \\
\hline 4 & SW, SC, GC & $1-20$ & $400-600$ & $600-900$ & $1800-2000$ & $0.200-0.400$ \\
\hline Half-space & Sandstone & $\sim$ & $500-760$ & $750-1140$ & $2000-2200$ & $0.100-0.300$ \\
\hline
\end{tabular}

Remarks: $\mathrm{OH}$ organic clay, $\mathrm{CH}$ high plasticity clay, $\mathrm{CM}$ silty clay, SM silty sand, SP poor-graded sand, SC clayey sand, SW well-graded sand, GC clayey gravel 
Table 2 Site classification based on $V_{530}$ (National Earthquake Hazard Reduction Provision, 1998)

\begin{tabular}{|c|c|c|}
\hline $\begin{array}{l}\text { NEHRP } \\
\text { Site Class }\end{array}$ & General Description & $\begin{array}{l}\text { Range of } V_{s 30} \\
{[\mathrm{~m} / \mathrm{s}]}\end{array}$ \\
\hline A & Hard Rock & $V_{s 30}>1500$ \\
\hline B & Rock & $760 \leq V_{530} \leq 1500$ \\
\hline C & Very Dense Soil and Soft Rock & $360 \leq V_{\mathrm{s} 30} \leq 760$ \\
\hline D & Stiff Soil $[15 \leq N \leq 50$ or $50 \mathrm{kPa} \leq N \leq 100 \mathrm{kPa}]$ & $180 \leq V_{\mathrm{s} 30} \leq 360$ \\
\hline E & Soil or any profile with more than 3 soft clay defiled as soil with $\mathrm{PI}>20, \mathrm{w} \geq 40 \%$, and $\mathrm{s}_{\mathrm{u}}<25 \mathrm{kPa}$ & $V_{530}<180$ \\
\hline $\mathrm{F}$ & Soils requiring site-specific evaluation & - \\
\hline
\end{tabular}

Remarks: $\mathrm{N}=\mathrm{SPT}$ value [blows/ft], $s_{u}$ undrained shear strength, $P$ I plasticity index, $w$ water content

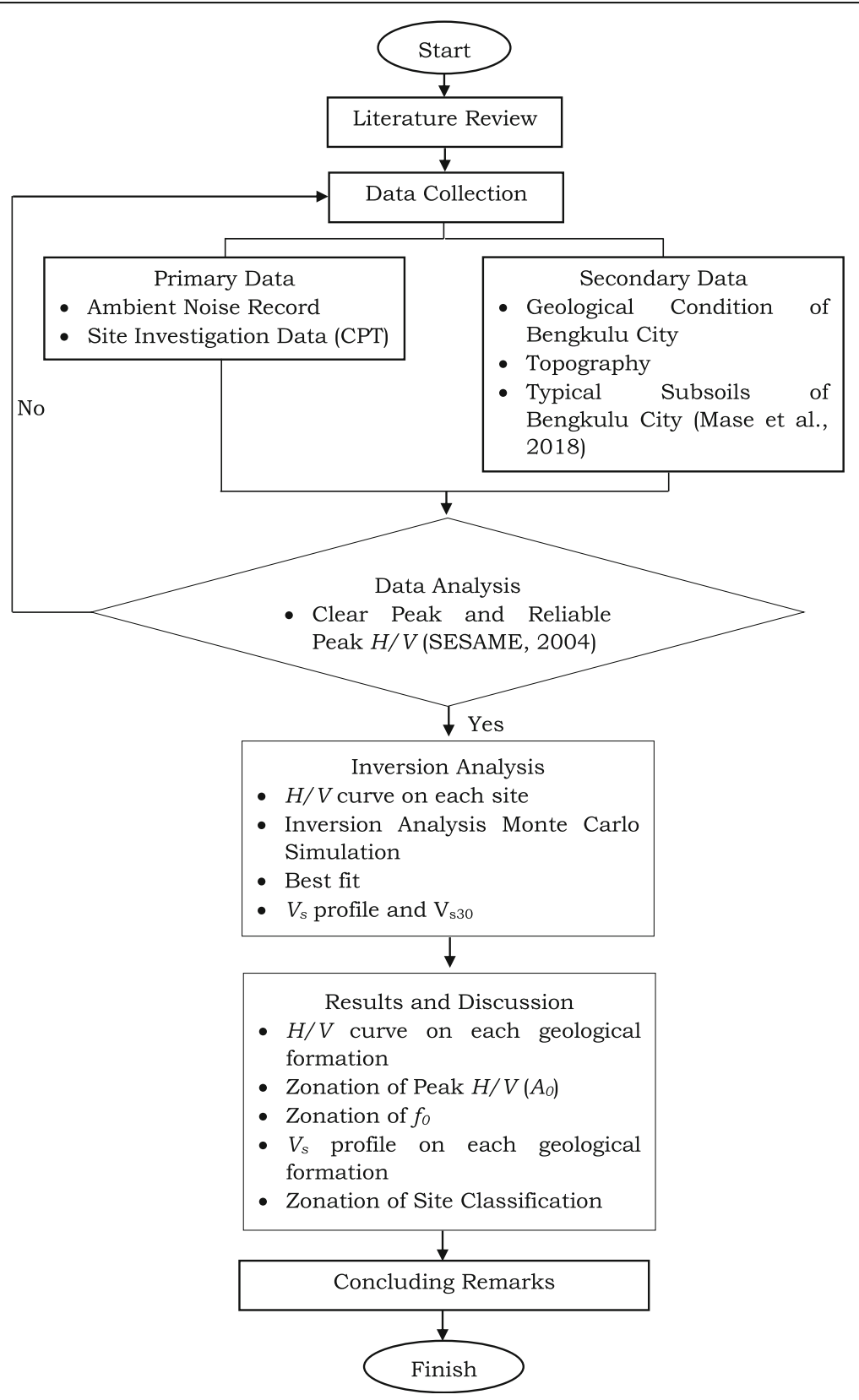

Fig. 4 Research framework 

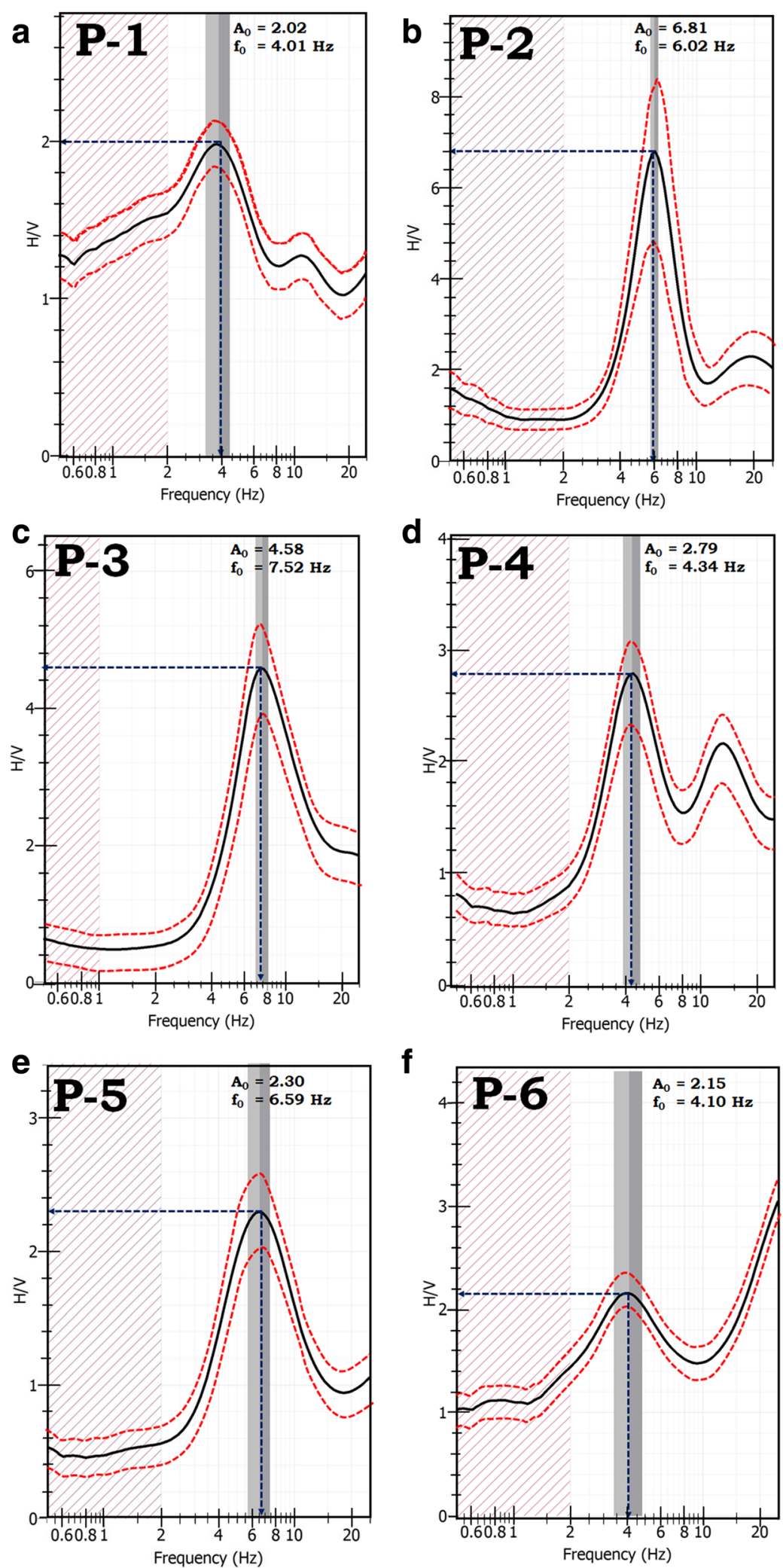

Fig. 5 HV curves at (a) P-1 (b) P-2 (c) P-3 (d) P-4 (e) P-5 and (f) P-6 


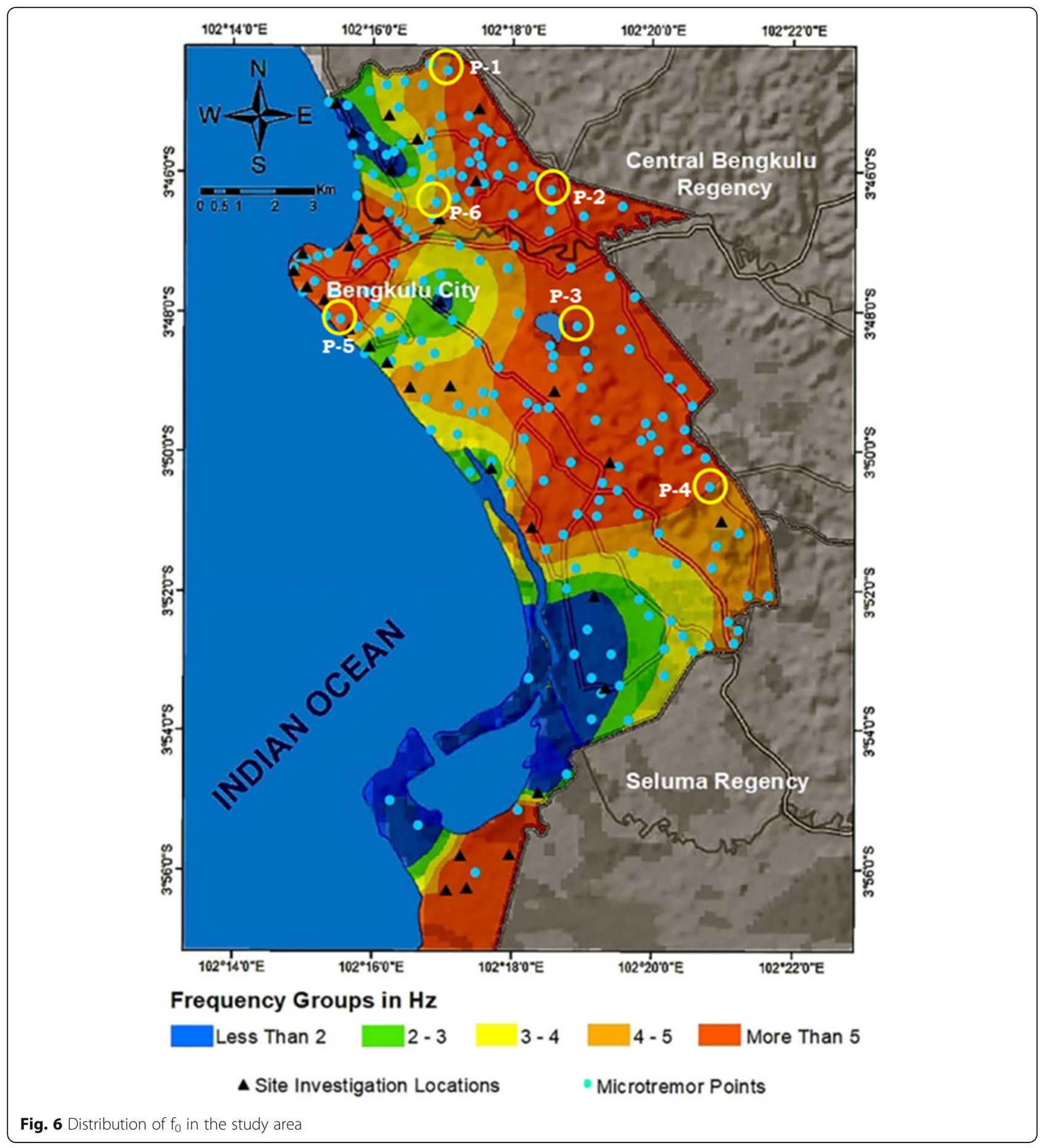

there is a thin sediment thickness in a site. It seems to be realistic, since P-3 and P-5 tend to have thin sediment thickness underlain by the bedrock. Materials such as sand, silt, mud and boulder are dominant in Qa. Those materials have certainly different characteristics, which are also possible to influence amplification. For P2 , the impedance contrast between sediment and bedrock is relatively smaller than P-3 and P-5 because $A_{O}$ is relatively smaller. The sediment thickness of $\mathrm{P}-2$ is relatively thinner than P-3 and P-5 sites because of larger $f_{0}$.

The flattered $H / V$ curves are presented by $\mathrm{P}-1$ and $\mathrm{P}-$ 4. Those sites represent Qs and Tpan, respectively. P-1 is located at swamp deposit dominated by sand, silt, 


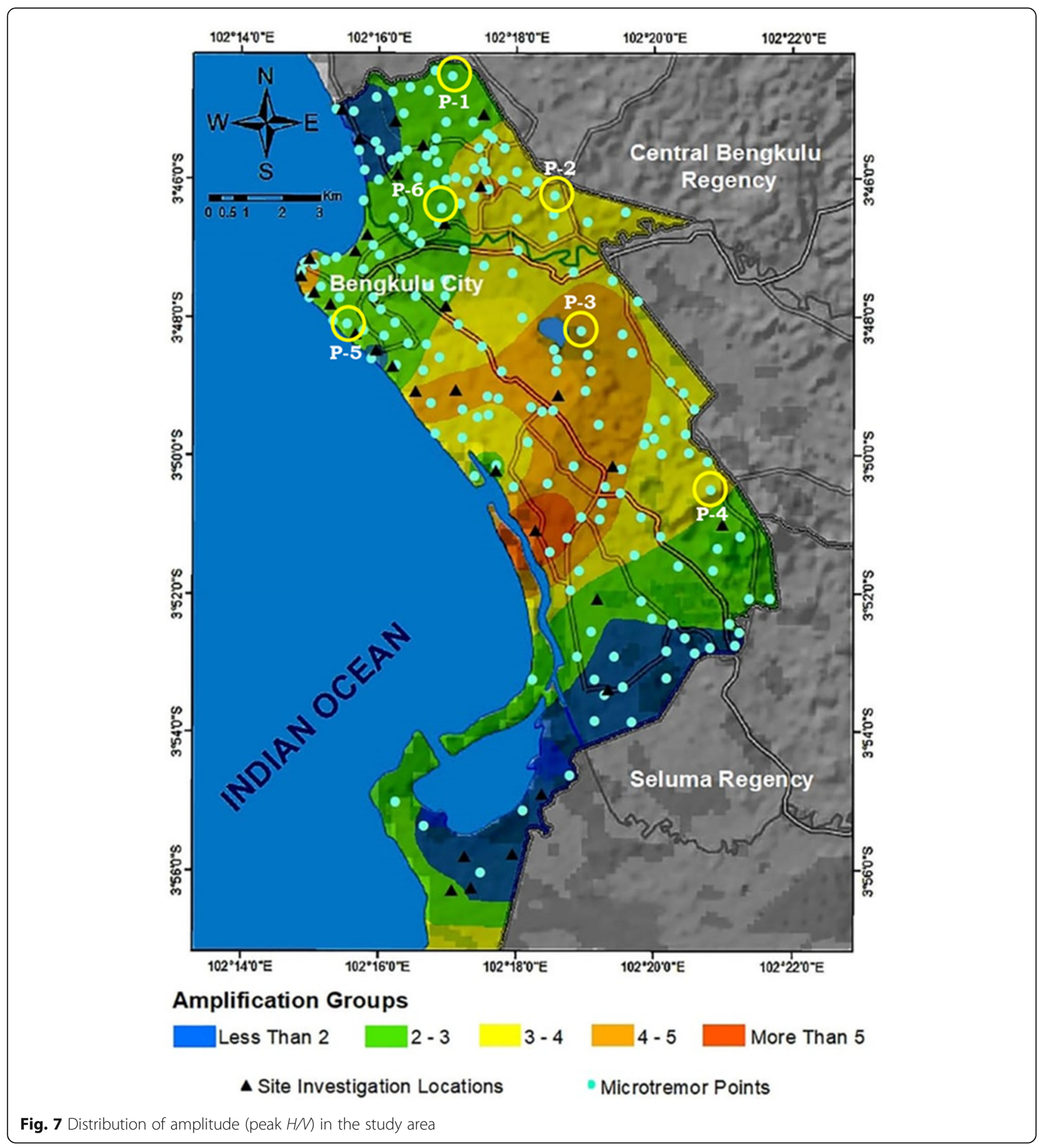

mud, clay with plant remains. Those materials seem to be underlain by shallow bedrock. P-4 site is located at andesite formation which has a thin sediment thickness underlain by bedrock. For those sites, $A_{O}$ are about 2.02 and 2.79, respectively, whereas values of $f_{0}$ are 4.01 and $4.34 \mathrm{~Hz}$, respectively. Both parameters indicate that there is a medium contrast between rock and sediment in P-1 and P-4. The $H / V$ curves also show that $f_{0}$ values are smaller than P-2, P-3, and P-5. P-6 which represents alluvium deposit is composed of sand, silt, clay, and gravel. Both $A_{O}$ and $f_{O}$ values are 2.15 and $4.10 \mathrm{~Hz}$, respectively. It indicates that impedance contrast between rock and sediment is relatively medium. Since $f_{0}$ value is quite large, thin sediment may be also found in this site. 


\section{Predominant frequency}

In Fig. 6, it can be seen that predominant frequency ranges are varied. There are five ranges representing distribution of predominant frequency. Those ranges can be grouped into high predominant frequency, medium predominant frequency, and low predominant frequency. Zone of high predominant frequency $\left(f_{0}>5 \mathrm{~Hz}\right)$ can be found on several areas in Bengkulu City, especially in southern part, south-eastern part and western part. Those areas are generally dominated by Qs, Qa, Qat, QTb, and Tpan. Gosar (2010) mentioned that a high $f_{O}$ indicates that a thin sediment thickness.

Zone of low predominant frequency $\left(f_{0}<3 \mathrm{~Hz}\right)$ is found along southern part (some parts of coastal area) and northern part. Those areas are mostly dominated by Qat and QTb. The materials, such as sand, silt, clay, and sandstone are found in this region. Several researchers, such as Misliniyati et al. (2018) and Mase (2017) predicted that sand deposit along coastal area of Bengkulu City could be very vulnerable to undergo liquefaction. In terms of sediment thickness, a low predominant frequency indicates a thick sediment thickness. Zone of medium predominant frequency $\left(3 \mathrm{~Hz} \leq f_{0} \leq 5 \mathrm{~Hz}\right)$ is concentrated in mid-plain of Bengkulu City. This area is generally dominated by Qa. Several sediment materials, such as sand and clay are found in this formation. Based on $f_{0}$ distribution, it can be predicted that sediment thickness at sites with medium predominant frequency is not much thicker than sediment thickness at sites with low predominant frequency. However, it may be thicker than sediment thickness at sites having high predominant frequency.

\section{Peak of $H / V$ amplitude $\left(A_{0}\right)$}

$A_{O}$ distribution (Fig. 7) is also divided into 5 categories, which can be grouped into low $A_{0}$, medium $A_{0}$, and high $A_{0}$. In general, medium $A_{0}\left(3 \leq A_{0} \leq 5\right)$ is dominant. Based on geological condition, medium $A_{0}$ areas are dominated by Qa, Qat, and Tpan. Gosar (2010) mentioned that a larger $A_{O}$ means a high impedance contrast between sediment and rock surface. The impedance contrast is the difference ability between the sediment and rock surface to propagate the seismic wave. Several areas, such as southern and northern parts of Bengkulu City have low $A_{O}\left(A_{O}<3\right)$. Those areas are also dominated by Qa, Qat, Qtb, and Qs formations. In terms of impedance contrast, a low $A_{O}$ indicates a low impedance contrast between sediment and rock surface. Small parts on the coastline of Bengkulu City indicate high $A_{O}\left(A_{O}>\right.$ 5). This area is dominated by Qat. $A_{0}$ is also related to the ability of sediment layer to amplify seismic wave propagation. Several studies (Mase, 2017; Misliniyati et al., 2018; Mase, 2020) had confirmed that sites along coastal area of Bengkulu City could amplify during the
Bengkulu-Mentawai Earthquake in 2007. Generally, the results are consistent with previous studies.

\section{$H / V$ comparison and $\mathrm{V}_{\mathrm{s}}$ profile}

The comparison between measured $H / V$ and inversion $H / V$ is presented in Fig. 8. Generally, for all representative sites, $H / V$ curves resulted from measurement and inversion are relatively consistent each other. However, measurement curves slightly underestimated inversion curves. This is due to the fact that the contrast of velocity in predicted models is rather stronger than real ground condition (Souriau et al., 2011).

Furthermore, $\mathrm{V}_{\mathrm{s}}$ profile from the best model resulted from inversion analysis is presented in Fig. 9. In general, $\mathrm{V}_{\mathrm{s}}$ profiles increase with depth up to $30 \mathrm{~m}$ depth. For first $30 \mathrm{~m}$ depth, $V_{\mathrm{s}}$ profiles consist of 4 to 5 layers. For P-2, P-3, P-4, P-5, thin layers with small difference of $V_{s}$ are found. It indicates that the layer could have similar soil resistance. In addition, those thin layers are probably dominated by $\mathrm{OH}$ and $\mathrm{CH}$, especially for first $2 \mathrm{~m}$ depth. Figure 9 also shows that $V_{s 30}$ values at representative sites are observed to vary from 307 to $409 \mathrm{~m} / \mathrm{s}$. Therefore, those sites can be categorised as Site Classes $\mathrm{C}$ and D. In Fig. 10, the results of inversion analysis are generally consistent with site investigation data. Representative sites having low $\mathrm{V}_{\mathrm{s}}$ and $\mathrm{N}$ values at shallow depth indicate that there is sediment materials, such as soft soils $(\mathrm{CH}$ and $\mathrm{OH})$. Another clayey soil called $\mathrm{CM}$ is also found at second layer that has larger $\mathrm{V}_{\mathrm{s}}$ than first layer. For third and fourth layers, granular materials which are composed of SM, SP, SC, SW, and GC, are found. Those materials are categorised as medium to dense sediments. The increase of $\mathrm{V}_{\mathrm{s}}$ and $\mathrm{N}$ values on those materials indicate the high density. At several representative sites, such as P-2 and P-3, engineering bedrock layers are also found. The layers are composed of sandstones with $V_{s}$ and $\mathrm{N}$ values relatively larger than previous layers. Generally, site investigation data of Bengkulu City are well correlated with $\mathrm{V}_{\mathrm{s}}$ profile obtained from inversion analysis.

\section{$V_{s 30}$ and seismic Hazard microzonation}

Figure 10 presents the contour of $V_{s 30}$ for Bengkulu City. In Fig. 10, there are five ranges of $V_{s 30}$, i.e. $V_{s 30}$ of 180 $240 \mathrm{~m} / \mathrm{s}, V_{s 30}$ of 240 to $300 \mathrm{~m} / \mathrm{s}, V_{s 30}$ of 300 to $360 \mathrm{~m} / \mathrm{s}$, $V_{s 30}$ of 360 to $420 \mathrm{~m} / \mathrm{s}$, and $V_{s 30}$ of 420 to $480 \mathrm{~m} / \mathrm{s}$. Several researchers, such as Thompson and Wald (2012), Cannon and Dutta (2015), and Silva et al. (2015) had also implemented the ranges to observe site characteristics at Taiwan, Alaska, and Portugal, respectively. In general, there are three dominant $V_{s 30}$ zones in Bengkulu City. The first one is $V_{s 30}$ of 360 to $420 \mathrm{~m} / \mathrm{s}$, which is centralised in the eastern part of Bengkulu City. The zone of $V_{s 30}$ of 300 to $360 \mathrm{~m} / \mathrm{s}$ is the second dominant 

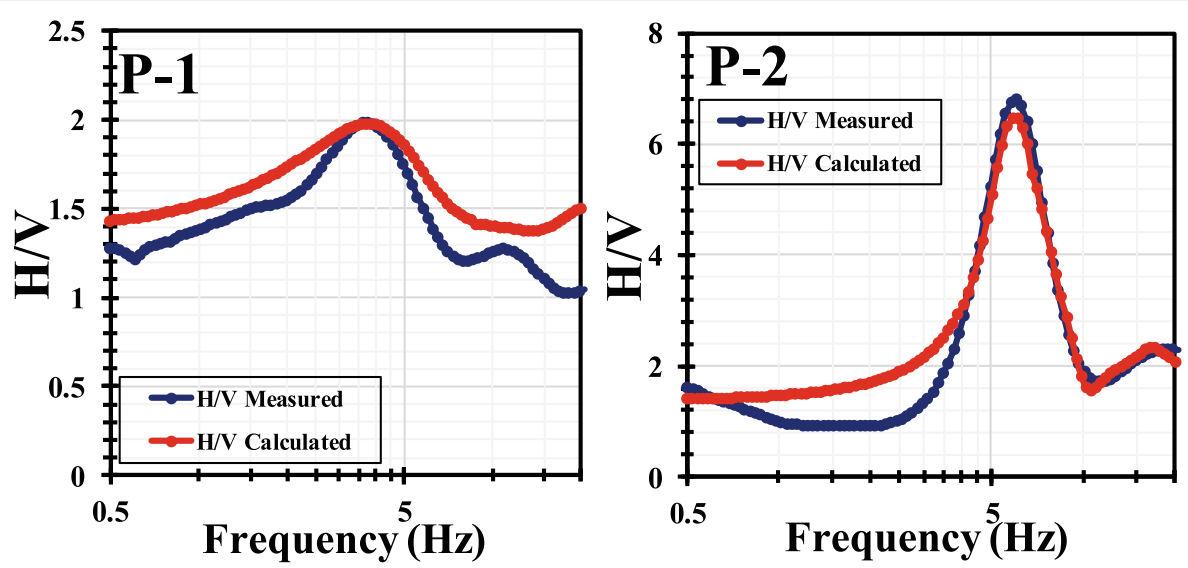

(a)
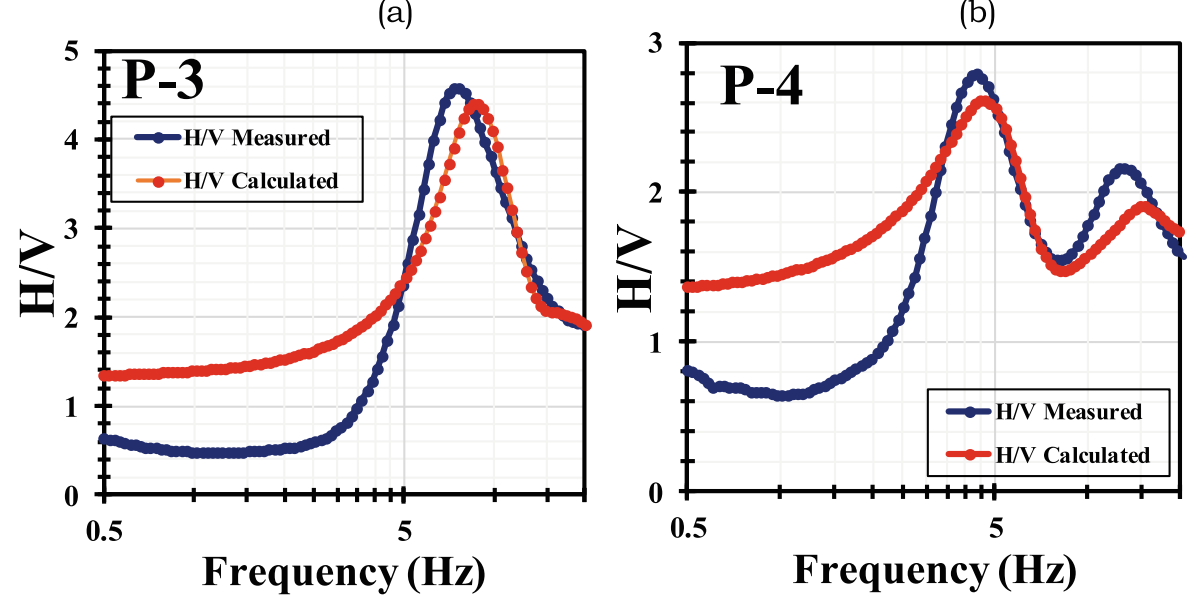

(c)

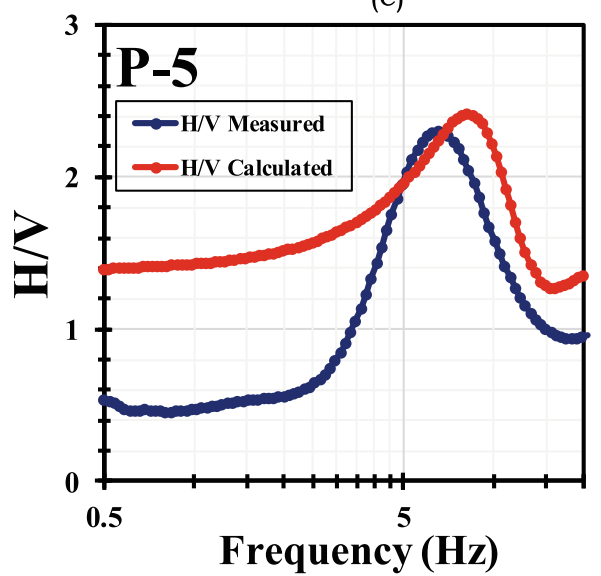

(d)

(d)

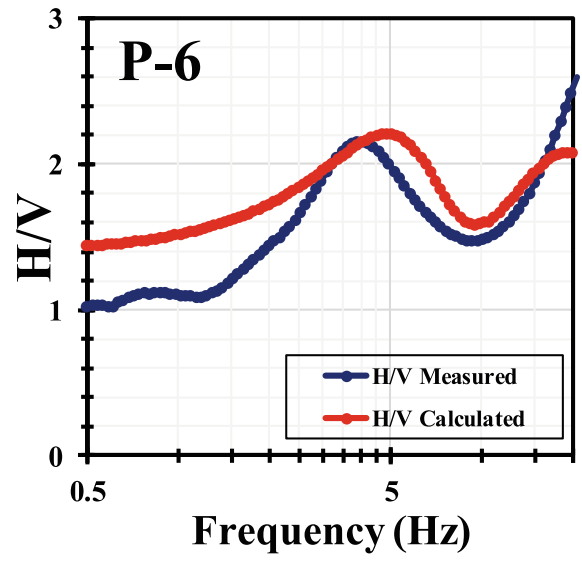

(e)

Comparison between $H / V$ measured and $H / V$ Inversion

Fig. 8 Comparison between $H N$ measured and HN Inversion

range in Bengkulu City. This zone is generally concentrated in the western part of Bengkulu City. The last dominant $V_{s 30}$ range is also concentrated along coastal area of Bengkulu City.

The description of seismic hazard microzonation is presented in Fig. 11. It can be seen that Bengkulu City is dominated by Site Class D (red colour). The map presents that most coastal areas are identified to have low $V_{s 30}$ values. $V_{s 30}$ values in those areas are generally within the range of $180 \mathrm{~m} / \mathrm{s}$ to $360 \mathrm{~m} / \mathrm{s}$, which fall into Site Class D. In terms of geological condition, Site Class $\mathrm{D}$ are dominated by sediment materials, such as sandy soils and soft clayey soils which have low soil resistances. Mase (2017) and Mase (2018) also explained that 


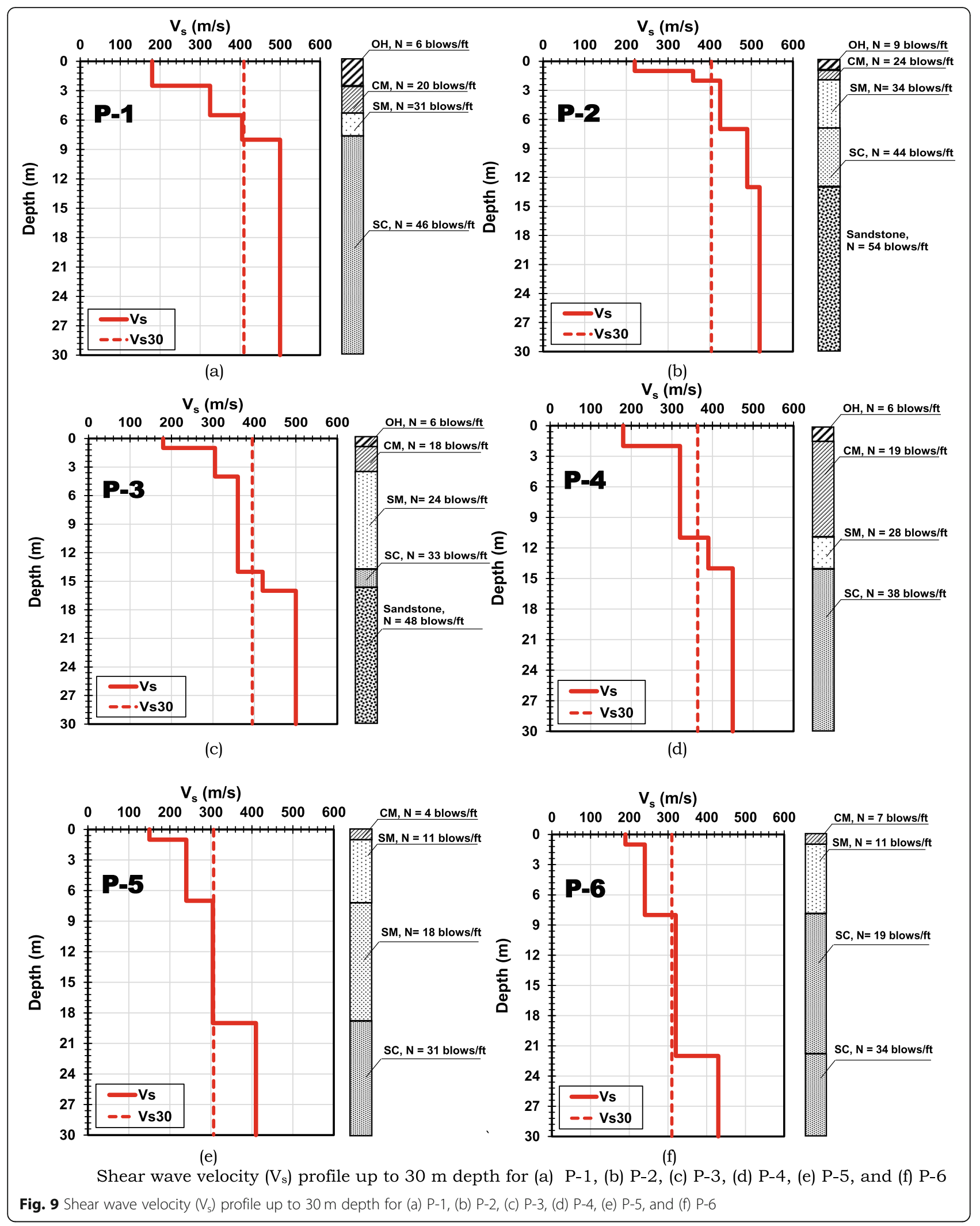




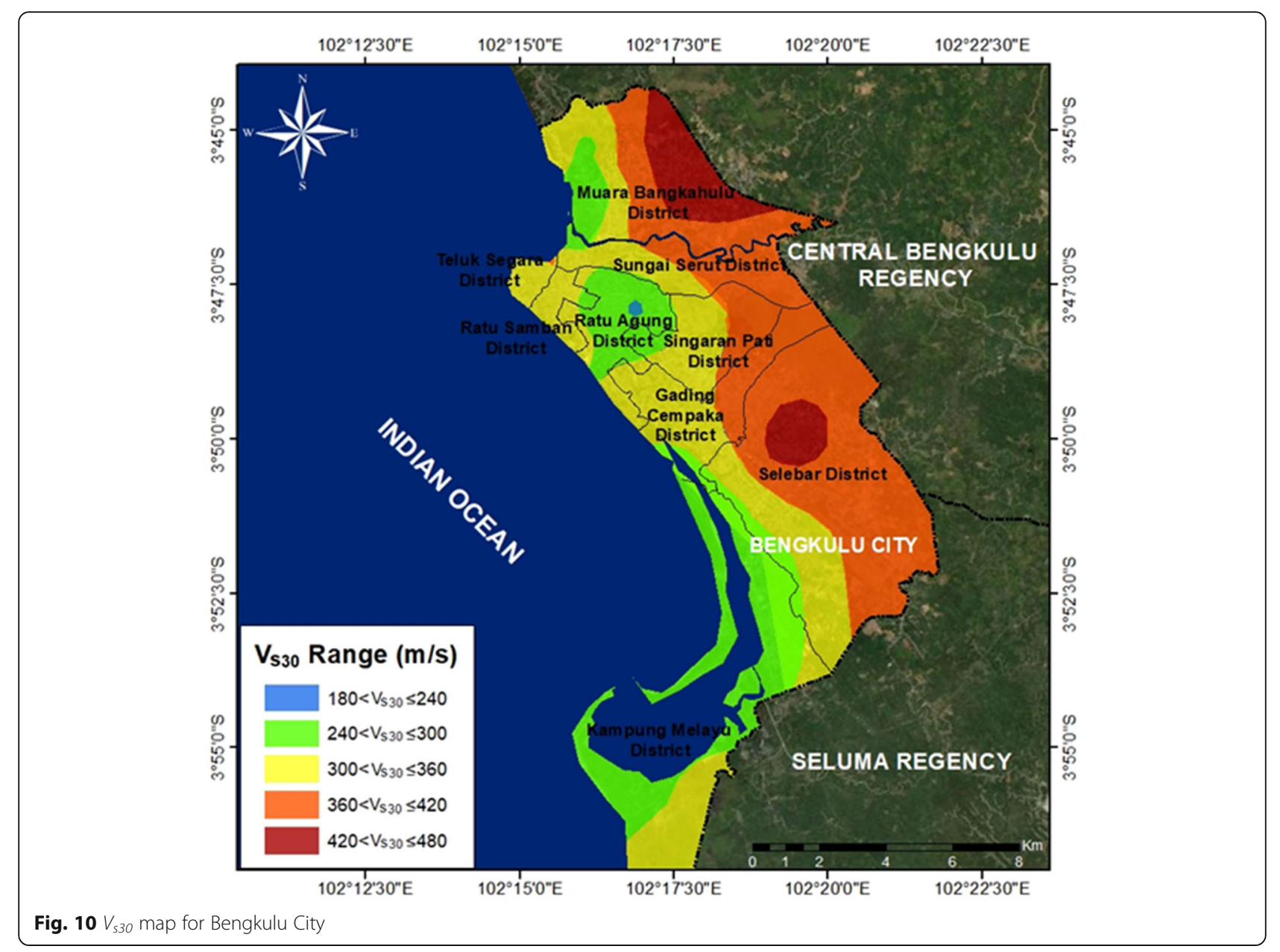

sediment materials with low soil resistances are very vulnerable to undergo seismic impact, such as liquefaction and ground amplification. In the eastern part of Bengkulu City, Site Class C ( $V_{s 30}$ within the range of 360 to $760 \mathrm{~m} / \mathrm{s}$ ), which is indicated by yellow colour is found. Generally, the eastern part of Bengkulu City is dominated by Tpan. This formation is composed of stiff materials. During the Bengkulu-Mentawai Earthquake, Mase (2017) and Misliniyati et al. (2018) reported that in the eastern part of Bengkulu City, there was no significant damage found. It might be due to larger soil resistance existing in this area. Meanwhile, liquefaction, ground failure and structural damage were massively found along coastal area of Bengkulu City. Based on the finding, it can be concluded that areas of Site Class C are relatively safer from seismic impacts. Other areas with similar site classes with Bengkulu City, such as Tauranga (Pearse-Danker and Wotherspoon, 2016), Rawalpindi-Islamabad (Khan and Khan, 2018), Himalayan Region (Anbazhagan et al., 2019), and Western Saudi Arabia (Alamri et al., 2020) had been also studied. Those methods are also used the same site classification method. Based on those previous studies, Site Class $\mathrm{C}$ is mostly found on areas underlain by relatively shallow bedrock dominated by rock and old alluvium deposits. Site Class D is commonly found on western part area of Bengkulu City which is dominated by alluvium terrace sediment. In Bengkulu City, the shallow bedrock areas are generally found on the high-terrain area (the eastern part of Bengkulu City) that is also dominated by rock and alluvium deposit. Different from Site Class C, Site Class D is concentrated at coastal area and western part of Bengkulu City. Those areas are also dominated by alluvium terrace sediment. In line with the characteristic of composed materials in those site classes, it can be concluded that general condition of site class in Bengkulu City is generally consistent with previous studies.

Overall, parameters of $f_{0}, A_{O}$ and $V_{s 30}$ are well correlated with geological condition in the study area. Misliniyati et al. (2018), Farid and Hadi (2018), and Farid and Mase (2020) mentioned that the updated spatial plan of Bengkulu City should consider seismic hazard microzonation. Strengthening on the mitigation effort is very important for Bengkulu City as one of vulnerable areas to 


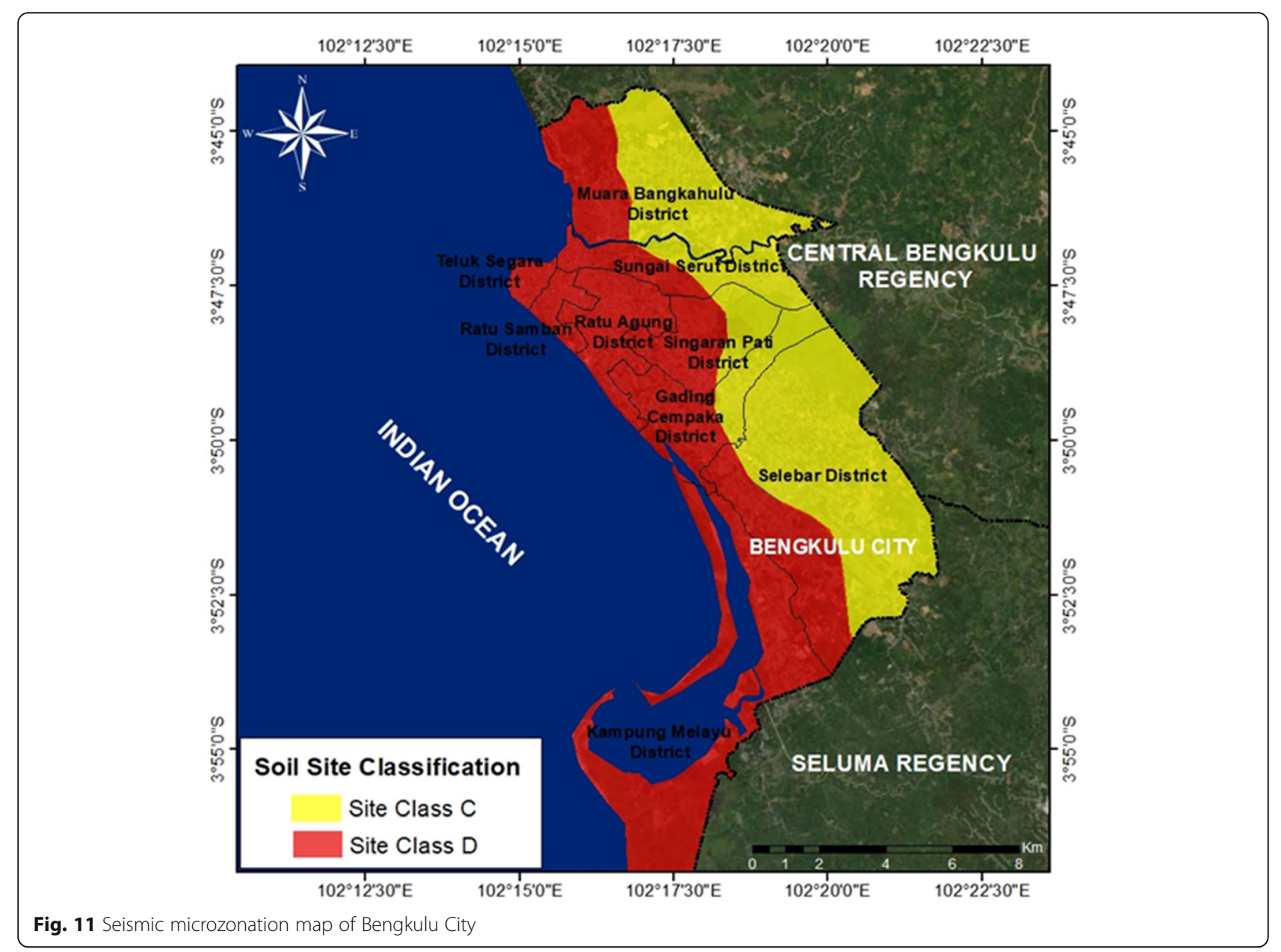

earthquake. The geophysical interpretations, such as $V_{s 30}$ and site classification maps can describe the potential impact of seismic hazard in Bengkulu City. Bengkulu City is being also now promoted as one of tourist areas in Indonesia. The development of infrastructures and facilities to support the goal would be significantly raising near future. However, seismic hazard of Bengkulu City has not totally understood by local engineers. Therefore, the information of seismic hazard mitigation could be used by local government to strengthen seismic mitigation effort in Bengkulu City. The results of this study would also contribute to recommend local engineers in designing buildings which prioritise on seismic hazard mitigation in Bengkulu City. The effort would effectively minimise the potential damage during earthquakes in Bengkulu City.

\section{Conclusion}

This paper presents the seismic hazard microzonation of Bengkulu City, Indonesia using the Inversion $H / V$ of microtremor observations. The higher density of observation points is presented in this study. The analysis of subsoils profiles are performed based on site investigation data and geophysical measurement. The inversion analysis using Monte Carlo simulation simulated annealing is performed to determine the best model of site condition. $A_{0}, f_{0}$ and $V_{s 30}$ are presented to characterise local site condition.

The geophysical parameters of site, such as $f_{O}$ and $A_{O}$ are relatively consistent with general geological condition of Bengkulu City. $f_{o}$ values can be used to estimate sediment thickness in the study area. Generally, Bengkulu City is dominated by Qs and Qat. The sediment thickness in the study area is relatively thin. From the information, it can be roughly estimated that bedrock surface in Bengkulu City may be located at shallow depth.

In Bengkulu City, most sites tend to have medium $A_{0}$. It indicates that there is a medium impedance contrast between rock surface and sediment. For Bengkulu City, these dominant zones are dominated by Qa and Qat. Those formations are composed of sediment materials, such as clay and sand. During the Bengkulu-Mentawai earthquake, the magnification of peak ground 
acceleration in these dominant zones are relatively large. Generally, field observations are consistent with evidence reported in previous studies.

This study also focused on seismic hazard microzonation in Bengkulu City. Site Class D is found on middle part to western part, whereas Site Class $C$ is found on eastern part. Site Class D tends to have a lower soil resistance. It indicates that seismic damage could be more serious. In general, Site Class D is located along coastal area of Bengkulu City, which is prospectively developed as tourist area in near future. Therefore, spatial plan on the basis of seismic hazard assessment should be carefully considered in Bengkulu City.

Overall, the implementation of geophysical survey to determine site characteristic is successfully performed in this study. The inversion technique to determine $V_{s}$ is reasonably performed. The results could provide a better understanding of seismic hazard mitigation in Bengkulu City. Finally, the results could give a recommendation to local government in updating the spatial plan in Bengkulu City. The framework implemented in this study can be used to investigate site characteristics in other areas.

\section{Abbreviations}

$H N$ : Horizontal to vertical spectral ratio; $V_{s}$ : Shear wave velocity; $V_{530}$ : Timeaveraged shear wave velocity for first $30 \mathrm{~m}$ depth; Qat: Alluvium terrace; Ql: Reef limestone; QTb: Bintunan formation; Tpan: Andesite formation; Qs: Swamp deposit; Qa: Alluvium deposit; $\mathrm{OH}$ : Organic clay; $\mathrm{CH}$ : High plasticity clay; CM: Silty clay; $q_{c}$ : cone resistance; SM: Silty sand; SP: Poorgraded sand; SC: Clayey sand; GC: Clayey gravel; To: Predominant period; $H_{(E W)}$ : Fourier amplitude spectra of horizontal in east-west direction; $H_{\text {(NS): }}$ Fourier amplitude spectra of horizontal in north-south directions; $; V$ : Fourier amplitude spectra of vertical; $f_{0}$ : predominant frequency; $A_{0}$ : Peak of HN amplitude; EW: East-west; NS: North-south; UD: Up-down; $V_{p}$ : Pressure wave velocity; $V_{s}$ : Shear wave velocity; $\rho$ : soil density; $v$ : Poisson's ratio; $V_{s i}$ : Shear wave velocity of each layer; $d_{i}$ : thickness of each layer; $n:$ number of layers for first $30 \mathrm{~m}$ depth; CPT: Cone penetration test; SPT: Standard penetration test; $\mathrm{N}$ : The number of blows of SPT test for $1 \mathrm{ft}$. penetration

\section{Acknowledgements}

This research was supported by Competitive Research Scheme from University of Bengkulu No. 2357/UN30.15/LT/2018. Authors would like to thank Soil Mechanics Laboratory and Geophysics Laboratory, University of Bengkulu for experiments and site investigations performed in this study.

\section{Authors' contributions}

Lindung Zalbuin Mase: Conceptualisation, Software, Validation, Formal analysis, Methodology, Data Analysis, Visualization, Writing-Original draftreview-editing, Mapping, Project Administration. Nanang Sugianto: Conceptualisation, Methodology. Refrizon: Conceptualisation, Methodology. The author(s) read and approved the final manuscript.

\section{Funding}

It is not applicable in this case.

\section{Availability of data and materials}

All the datasets that have been used and analysed during the current study is available from the corresponding author on reasonable request.

\section{Competing interests}

I have declare that there is no any competing interests.

\section{Author details}

'Department of Civil Engineering, Faculty of Engineering, University of Bengkulu, WR Supratman Road, Kandang Limun, Muara Bangkahulu, Bengkulu 38371, Indonesia. ${ }^{2}$ Department of Geophysics, Faculty of Mathematics and Natural Sciences, University of Bengkulu, WR Supratman Road, Bengkulu 38371, Indonesia.

Received: 11 July 2020 Accepted: 8 February 2021

Published online: 25 February 2021

\section{References}

Adampira M, Alielahi H, Panji M, Koohsari H (2015) Comparison of equivalent linear and nonlinear methods in seismic analysis of liquefiable site response due to near-fault incident waves: a case study. Arab J Geosci 8(5):3103-3118. https://doi.org/10.1007/s12517-014-1399-6

Alamri AM, Bankher A, Abdelrahman K, El-Hadidy M, Zahran H (2020) Soil site characterization of Rabigh city, western Saudi Arabia coastal plain, using HVSR and HVSR inversion techniques. Arab J Geosci 13(2):1-16. https://doi. org/10.1007/s12517-019-5027-3

Anbazhagan P, Srilakshmi KN, Bajaj K, Moustafa SS, Al-Arifi NS (2019) Determination of seismic site classification of seismic recording stations in the Himalayan region using HVSR method. Soil Dyn Earthq Eng 116:304-316. https://doi.org/10.1016/j.soildyn.2018.10.023

Atakan K (2009) The need for standardized approach for estimating the local site effects based on ambient noise recordings. In: Mucciarelli M, Herak M, Cassidy JF (eds) Proc of the NATO advanced research workshop on increasing seismic safety by combining engineering technologies and seismological data. The NATO science for peace and security series-C: environmental security, XVIII, Dubrovnik, Croatia, pp 19-21 September: pp 315

Bard PY (2004) The SESAME-FP5 project: an overview and main results. Proc of the 13th World Conference on Earthquake Engineering, Vancouver, Canada, pp 1-6

Bonnefoy-Claudet S, Cornou C, Bard PY, Cotton F, Moczo P, Kristek J, Fah D (2006) H/Vratio: a tool for site effects evaluation. Results from 1-D noise simulations. Geophys J Int 167(2):827-837. https://doi.org/10.1111/j.1365-24 6X.2006.03154.x

Cannon EC, Dutta U (2015) Evaluating topographically-derived $V_{s 30}$ values for seismic site class characterization in Anchorage, Alaska, USA. Proc of the 6th international conference on earthquake geotechnical engineering, 2-4 November, Christchurch, New Zealand

Dev SMSP, Nagarajan R (2017) Seismic hazard assessment of Koyna region, peninsular India: using geospatial approach. Geoenviron Disasters 4(1):1-10. https://doi.org/10.1186/s40677-017-0092-y (online first)

El-Hady S, Fergany EAA, Othman A, Mohamed GEA (2012) Seismic microzonation of Marsa Alam, Egypt using inversion HVSR of microtremor observations. J Seismol 16(1):55-66. https://doi.org/10.1007/s10950-011-9249-4

Farid M, Hadi Al (2018) Measurement of shear strain in map liquefaction area for earthquake mitigation in Bengkulu City. Telkomnika 16(4):1597-1606. https:// doi.org/10.12928/TELKOMNIKA.v16i4.8043

Farid M, Mase LZ (2020) Implementation of seismic hazard mitigation on the basis of ground shear strain indicator for spatial plan of Bengkulu City, Indonesia. Int J Geomate 18(69):199-207. https://doi.org/10.21660/2020.69.24759

García-Jerez A, Piña-Flores J, Sánchez-Sesma FJ, Luzón F, Perton M (2016) A computer code for forward computation and inversion of the $\mathrm{H} / \mathrm{N}$ spectral ratio under the diffuse field assumption. Comput Geosci 97(1):67-78. https:// doi.org/10.1016/j.cageo.2016.06.016

Gosar A (2010) Site effects and soil-structure resonance study in the Kobarid basin (NW Slovenia) using microtremors. Nat Hazards Earth Sys Sci 10(4):761772. https://doi.org/10.5194/nhess-10-761-2010

Imai T, Tonouchi K (1982) Correlation of N-value with S-wave velocity. Proc. of 2nd European symposium on penetration testing, 67-72, Amsterdam, Netherland, may 24-27

Kanai K, Tanaka T (1954) Measurement of the microtremor. Bull Earthq Res Ins 32(1):199-209

Khan S, Khan MA (2018) Seismic microzonation of Islamabad-Rawalpindi metropolitan area, Pakistan. Pure Appl Geophys 175(1):149-164. https://doi. org/10.1007/s00024-017-1674-z

Koçkar MK, Akgün H (2012) Evaluation of the site effects of the Ankara basin, Turkey. J Appl Geophys 83(1):120-134. https://doi.org/10.1016/j.jappgeo.2012. 05.007 
Lachet C, Bard PY (1994) Numerical and theoretical investigations on the possibilities and limitations of Nakamura's technique. J Phys Earth 42(5):377397

Lachet C, Hatzfeld D, Bard PY, Theodulidis N, Papaioannou C, Savvaidis A (1996) Site effects and microzonation in the city of Thessaloniki (Greece) comparison of different approaches. Bull Seismol Soc America 86(6):16921703

Likitlersuang S, Plengsiri P, Mase LZ, Tanapalungkorn W (2020) Influence of spatial variability of ground on seismic response analysis: a case study of Bangkok subsoils. Bull Eng Geol Environ 79(1):39-51

Mase LZ (2017) Liquefaction potential analysis along coastal area of Bengkulu Province due to the $2007 M_{w} 8.6$ Bengkulu earthquake. J Eng and Technol Sci 49(6):721-736 DOl: 10.5614\%2Fj.Eng.Technol.Sci.2017.49.6.2

Mase LZ (2018) Reliability study of spectral acceleration designs against earthquakes in Bengkulu City, Indonesia. Int J Technol 9(5):910-924. https:// doi.org/10.14716/ijtech.v9i5.621

Mase LZ (2019) Seismic vulnerability maps of Ratu Agung District, Bengkulu City, Indonesia. Civil Eng Dimens 21(2):97-106. https://doi.org/10.9744/ced.21.2 97-106

Mase LZ (2020) Seismic Hazard vulnerability of Bengkulu City, Indonesia, based on deterministic seismic Hazard analysis. Geotech Geol Eng 38:5433-5455. https://doi.org/10.1007/s10706-020-01375-6

Mase LZ (2021) A note of ground motion interpretation and site response analysis during the 2007 Bengkulu-Mentawai earthquakes, Indonesia. Arab J Geosci 14(2):1-14. https://doi.org/10.1007/s12517-020-06344-0

Mase LZ, Agustina S, Anggraini PW (2020a) Seismic hazard microzonation of ground response parameters in Bengkulu City, Indonesia. IOP Conference Series Earth Environ Sci 528(1):012051. https://doi.org/10.1088/1755-1315/52 $8 / 1 / 012051$

Mase LZ, Likitlersuang S, Tobita T (2018a) Non-linear site response analysis of soil sites in northern Thailand during the $M_{w} 6.8$ Tarlay earthquake. Eng J 22(3): 291-303. https://doi.org/10.4186/ej.2018.22.3.291

Mase LZ, Likitlersuang S, Tobita T (2018b) Analysis of seismic ground response caused during strong earthquake in northern Thailand. Soil Dyn Earthq Eng 114:113-126. https://doi.org/10.1016/j.soildyn.2018.07.006

Mase LZ, Likitlersuang S, Tobita T (2020c) Ground motion parameters and resonance effect during strong earthquake in northern Thailand. Geotech Geol Eng:1-13. https://doi.org/10.1007/s10706-020-01619-5 (online first)

Mase LZ, Likitlersuang S, Tobita T, Chaiprakaikeow S, Soralump S (2020b) Local site investigation of liquefied soils caused by earthquake in northern Thailand. J Earthq Eng 24(7):1181-1204. https://doi.org/10.1080/13632469.201 8.1469441

Mase LZ, Refrizon R, Anggraini PW (2021) Local site investigation and ground response analysis on downstream area of Muara Bangkahulu River, Bengkulu City, Indonesia. Indian Geotech J:1-15. https://doi.org/10.1007/s40098-02000480-w (online first)

Mase LZ, Sugianto N, Refrizon (2018c) Shear wave velocity mapping for spatial plan of Bengkulu City. Report of competitive Reserch no. 2357/UN30.15/LT/ 2018. University of Bengkulu, Bengkulu

McCaffrey R (2009) The tectonic framework of the Sumatran subduction zone. Annu Rev Earth Planet Sci 37:345-366. https://doi.org/10.1146/annurev.earth. 031208.100212

McCloskey J, Lange D, Tilmann F, Nalbant SS, Bell AF, Natawidjaja DH, Rietbrock A (2010) The September 2009 Padang earthquake. Nat Geosci 3(2):70-71. https://doi.org/10.1038/ngeo753

Misliniyati R, Mase LZ, Irsyam M, Hendriawan H, Sahadewa A (2019) Seismic response validation of simulated soil models to vertical array record during a strong earthquake. J Eng Technol Sci 51(6):772-790. https://doi.org/10.5614/j. eng.technol.sci.2019.51.6.3

Misliniyati R, Mase LZ, Syahbana AJ, Soebowo E (2018) Seismic hazard mitigation for Bengkulu coastal area based on site class analysis. IOP Conference Series Earth Environ Sci 212(1):012004. https://doi.org/10.1088/1755-1315/212/1/012004

Nakamura Y (1989) A method for dynamic characteristic estimation of subsurface using microtremor on ground surface. Q Report Railway Technical Res 30(1): 25-53

Natawidjaja DH, Triyoso W (2007) The Sumatran fault zone-from source to hazard. J Earthq Tsunami 1(1):21-47. https://doi.org/10.1142/S17934311 07000031

National Earthquake Hazards Reduction Program (1998) Recommended Provisions for Seismic Regulation for New Buildings and Other Structures: Part 1-Provisions and Part 2- Commentary. FEMA 302, Texas, USA
Natural Disaster Agency of Bengkulu Province (2018) Geological map of Bengkulu City, Indonesia. Natural Disaster Agency of Bengkulu Province, Bengkulu

Pearse-Danker E, Wotherspoon L (2016) Site subsoil class determinations in Tauranga. NZ Geomechanics News, pp 62-71

Raptakis DG, Manakou MV, Chavez-Garcia FJ, Makra KA, Pitilakis KD (2005) 3D configuration of mygdonian basin and preliminary estimate of its site response. Soil Dyn Earthq Eng 25(1):871-887. https://doi.org/10.1016/j. soildyn.2005.05.005

Rusydy I, Idris Y, Muksin U, Cummins P, Akram MN (2020) Shallow crustal earthquake models, damage, and loss predictions in Banda Aceh, Indonesia. Geoenviron Disasters 7(1):1-16. https://doi.org/10.1186/s40677-020-0145-5 (online first)

Salencon J (2001) Handbook of continuum mechanics: general concepts, Thermoelasticity. Springer Science and Business Media, Berlin

SESAME (2004) Guidelines for the implementation of the H/N spectral ratio technique on ambient vibrations: measurements, processing and interpretation. http://sesame-fp5.obs.ujf-grenoble.fr/Delivrables/Del-D23HV_ User_Guidelines.pdf. Accessed 28 September 2019

Sieh K, Natawidjaja DH (2000) Neotectonics of the Sumatran fault, Indonesia. J Geophys Research: Solid Earth 105(B12):28295-28326. https://doi.org/10.102 9/2000JB900120

Silva V, Crowley H, Varum H, Pinho R (2015) Seismic risk assessment for mainland Portugal. Bull Earthq Eng 13(2):429-457. https://doi.org/10.1007/s10518-0149630-0

Souriau A, Chaljub E, Cornou C, Margerin L, Calvet M, Maury M, Wathelet M, Grimaud F, Ponsolles C, Pequegnat C, Langlais M, Guéguen P (2011) Multimethod characterization of the French-Pyrenean valley of Bagnères-deBigorre for seismic-hazard evaluation: observations and models. Bull Seismo Soc America 101(4):1912-1937. https://doi.org/10.1785/0120100293

Tao Y, Rathje E (2020) Taxonomy for evaluating the site-specific applicability of one-dimensional ground response analysis. Soil Dyn Earthq Eng 128:105865. https://doi.org/10.1016/j.soildyn.2019.105865

Tatham TH (1982) Vp/Ns and lithology. Geophysics 47(3):336-344

Thompson EM, Wald DJ (2012) Developing $V_{\$ 30}$ site-condition maps by combining observations with geologic and topographic constraints. In: Proc of the 15th world conference on earthquake engineering, 24-28 September, Lisbon, Portugal

Wathelet M (2008) An improved neighbourhood algorithm: parameter conditions and dynamic scaling. Geophys Res Lett 35(1):1-5. https://doi.org/10.1029/2 008GL033256

Widiwijayanti C, Déverchère J, Louat R, Sébrier M, Harjono H, Diament M, Hidayat $D$ (1996) Aftershock sequence of the 1994, $M_{w}$ 6.8, Liwa earthquake (Indonesia): Seismic rupture process in a volcanic arc. Geophys Res Lett 23(21):3051-3054. https://doi.org/10.1029/96GL02048

Zhao JX, Xu H (2013) A comparison of $V_{\$ 30}$ and site period as site-effect parameters in response spectral ground-motion prediction equations. Bull Seismol Soc Am 103(1):1-18. https://doi.org/10.1785/0120110251

\section{Publisher's Note}

Springer Nature remains neutral with regard to jurisdictional claims in published maps and institutional affiliations.

\section{Submit your manuscript to a SpringerOpen ${ }^{\circ}$ journal and benefit from:}

- Convenient online submission

- Rigorous peer review

- Open access: articles freely available online

High visibility within the field

Retaining the copyright to your article

Submit your next manuscript at $>$ springeropen.com 